\title{
A new species of Myxomycetes, Physarum apiculosporum, described and cultivated
}

\author{
MARJA HÄRKÖNEN
}

\begin{abstract}
HÄRKÖNEN, M. 1978: A new species of Myxomycetes, Physarum apiculosporum, described and cultivated. - Karstenia 18: 24-26.

A new species of Myxomycetes, Physarum apiculosporum Härkönen, is described from Finland. It was first obtained on Hordeum seeds in moist chamber culture. It resembles Physarum ovisporum G. Lister in being grey, sessile, sporangiate or plasmodiocarpous and having oval spores. The spores differ from those of $P$. ovisporum in being more oval, bigger, darker, smooth and apiculate. It was possible to cultivate the species from spore to spore in a simple medium of boiled Avena seeds on filter paper in a Petri dish.
\end{abstract}

Marja Härkönen, Department of Botany, University of Helsinki, Unioninkatu 44, SF-00170 Helsinki 17, Finland

Physarum apicullosporum Härkönen n. sp.

Sporangia et plasmodiocarpia gregaria, sessilia, pulvinata, $0.3-0.8 \mathrm{~mm} \times$ ad $5 \mathrm{~mm}$ diam. Peridium tenue, membranaceum, cinereum, leviter iridescens, granulis calcareis albis rugosum. Hypothallus inconspicuus, membranaceus, angustus. Columella $a b$ sens. Capillitium tubulis gracilibus, hyalinis, nodis calcareis parvis, albis, rotundatis praeditis. Massa sporarum nigra. Sporae luce transmissa purpureobrunneae, laeves, ovatae, apiculatae, 8-9.1-10 $\times$ 10-11.8-14 $\mu \mathrm{m}$ diam. Plasmodium hyalinum flavum.

Holotypus: Finlandia, Kainuu, Vaala, in vitro ad semina Avenae sativae, 6.II.1978 M. Härkönen 1335 (H).

Sporangia and simple or branched plasmodiocarps gregarious, sessile, pulvinate, $0.3-0.8 \mathrm{~mm} \times$ up to $5 \mathrm{~mm}$ in diam. Peridium grey, somewhat iridescent, roughened with deposits of white lime granules. Dehiscence irregular. Hypothallus inconspicuous, narrow, transparent with or without lime. No columella. Capillitium tubules thin, hyaline with small, white, rounded or somewhat angular lime nodes. Spores black in mass, purple brown in transmitted light, oval (appearing globose when viewed from end), smooth with an apiculus at one or both ends and some having a pale line of dehiscence, $8-9.1-10 \times 10-11.8-14 \mu \mathrm{m}$ in diam. Plasmodium hyaline to yellow, turning milky when beginning to coalesce. Developing sporophores turning black, and grey spots then appearing on surface of sporangia. During maturation sporangia turning ashgrey from deposits of lime. (Sporangia with only a few lime granules stay nearly black, as black spore mass shines through the transparent peridium.)

Type: Finland. Cultured in moist chamber on seeds of Avena sativa, from spores originating in Kainuu, Vaala, on seeds of Hordeum vulgare, 6.II.1978 M. Härkönen 1335 (H, holotype; herb. N. E. Nannenga-Bremekamp, isotype).

Other material examined: The ancestor and descendants of the type.

\section{Discussion}

The species was found in a moist chamber culture during an investigation on Myxomycetes developing on cereal seeds collected from Finnish fields (Härkönen \& Koponen 1978). In the original culture only two small plasmodiocarps and one sporangium emerged on seeds of Hordeum vulgare. Their most distinctive feature is the oval shape of the spores, which suggests Physarum ovisporum G. Lister. Martin \& Alexopoulos (1969) doubted the validity of that species, since the specimens that they studied did not have oval spores as stated in the original description (Lister 1921). After having studied Lister's material of $P$. ovisporum, Farr (1976) treated it as a synonym of $P$. vernum Somm., which according to Hagelstein (1944) is the species 

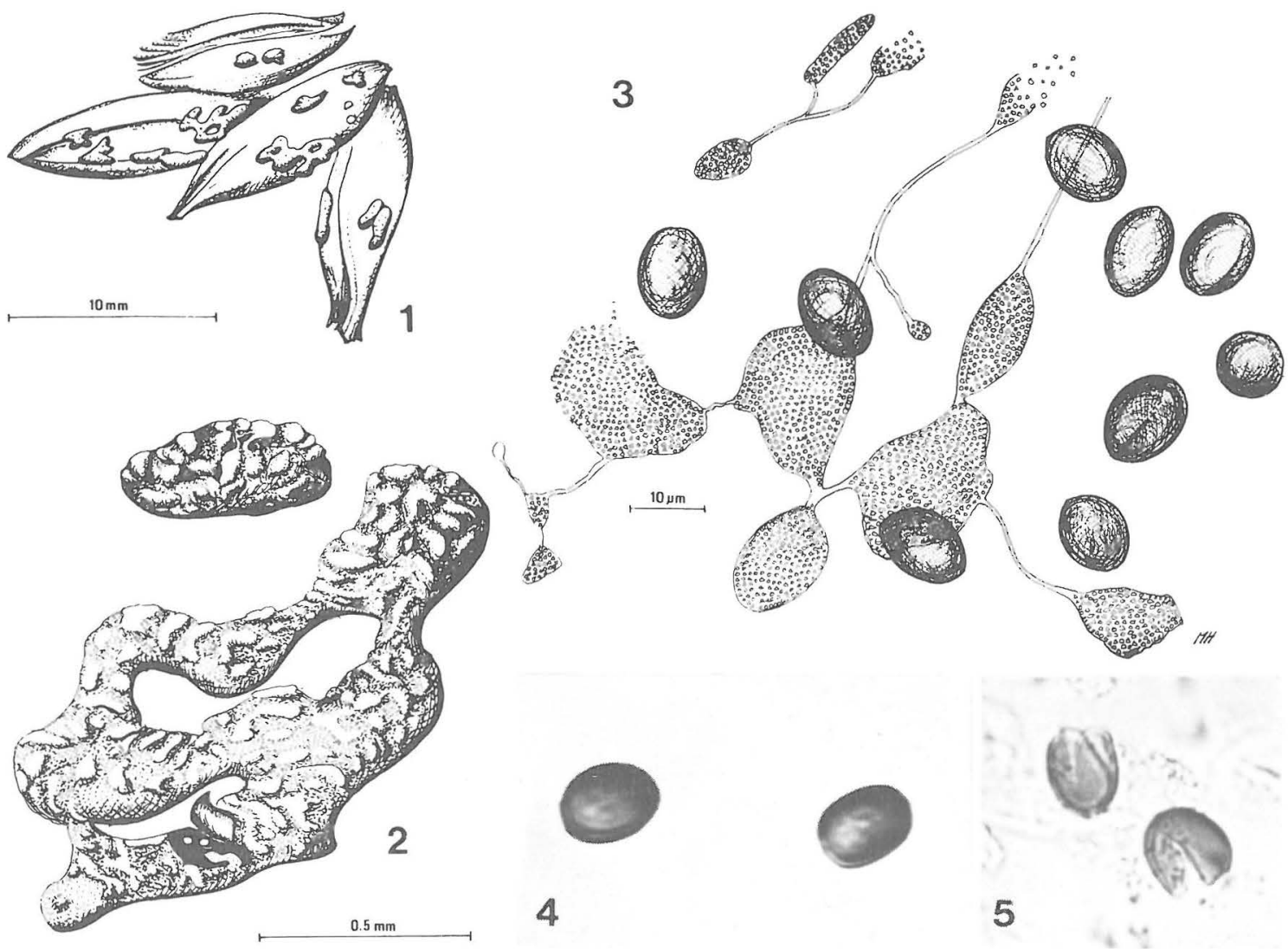

Figs. 1-5. Physarum apiculosporum. - 1: Sporophores on seeds of Avena. - 2: A sporangium and a plasmodiocarp. 3: Capillitium and spores. - 4: Spores of the first generation. - 5: Spores of the second generation after the swarm cells have escaped $\times 900$.

closest to $P$. ovisporum. In the present specimen, however, the spores clearly show the oval shape (Figs. 3-4) that Lister (1921) considered to be restricted to $P$. ovisporum in this genus.

Probable type specimens of $P$. ovisporum, G. Lister 3091, 3976 (slide only) and 2450 (slide only), kindly sent to me from BM, London, were compared with the present material. In $P$. ovisporum the sporophores are somewhat bigger and have a distinct crust of lime, and the lime nodes in the capillitium are more numerous and completely round. The spores are somewhat smaller, lighter, spinulose and only partially and slightly oval (7.5-8.8-10.5 $\times 7.5-9.9-12 \mu \mathrm{m}$ in diam.), many having a pale line of dehiscence (Fig. 6).

Smooth or oval spores are rare among Myxomycetes. Only Badhamia ovispora auct. (sensu Lister 1925 and Martin \& Alexopoulos 1969, etc.) has smooth ellipsoid spores. That species is not conspecific with the original B. ovispora Racib. 1884
(Keller et al. 1975) and is thus shown to be unnamed. The present specimen, however, differs from the descriptions of $B$. ovispora sensu Lister in having clearly physaroid capillitium, dark spores and a single peridium, and so must represent an undescribed species.

To test the viability of the spores and the constancy of their shape (see Alexopoulos 1969) I tried to cultivate them about half a year after their formation. They were put into hanging drops on cover glasses cemented to glass rings on objective slides. In three days the spores produced swarm cells. A new habitat was made to correspond to the moist chamber used to cultivate the original sporophores from Vaala. Avena sativa caryopses were boiled for ten minutes in distilled water to kill possible other Myxomycete spores and then put into sterilized Petri dishes lined with filter paper. The hanging drops with swarm cells were transferred into a thin layer of distilled water in these moist 
chambers. Some spores were sown directly in other sterilized Petri dishes with boiled Avena seeds. As after two week's incubation no plasmodia had appeared, some of the Petri dishes were dried and rewetted after three days. These moist chambers never produced any Myxomycetes.

After 23 days from the beginning of the experiment very weak colourless and yellow plasmodia could be seen in one Petri dish. On the 30th day plasmodia were coalescing. The covers were partially removed to let the substrate dry gradually. Depending on the amount of moisture, it took one to two more days for the sporangia to mature. In three dishes the sporophores and spores were like those in the original material. They serve as type material.

On the day after maturation the new-formed spores were cultivated in hanging drops. After 20 hours the hanging drops were full of swarm cells, amoebae and microcysts. The species is thus not one of those Myxomycetes whose spores need a time of after-ripening (Gray \& Alexopoulos 1968). Closer observation showed that the first spores began to germinate one hour after being placed in water. (This time is short, but not exceptional; Smart (1937) got Fuligo septica to germinate in 15 minutes.) The germinating spores ruptured along a lighter ridge, which is visible in some spores and becomes more obvious just before germination (Fig. 5). These swarm cells produced sporophores of the third generation in 10 days.

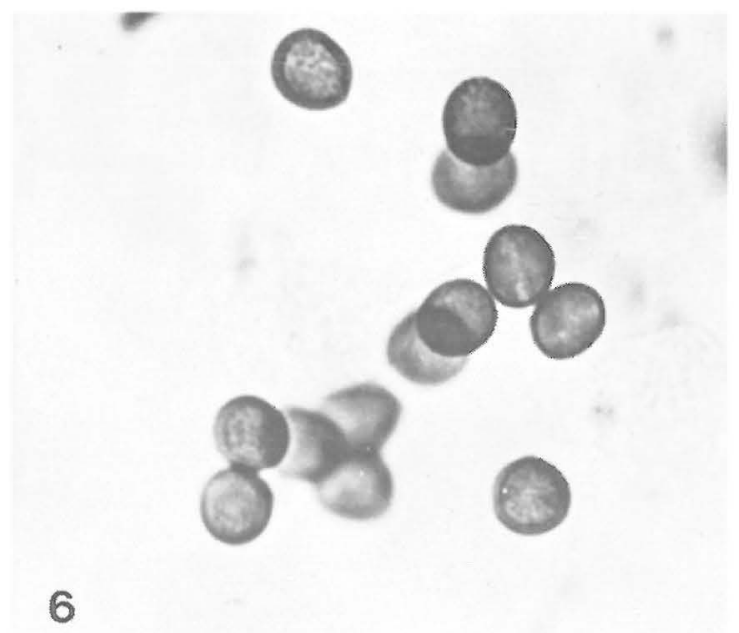

Fig. 6. Physarum ovisporum (G. Lister 3091). Spores $\times$ 900 .

\section{References}

Alexopoulos, C. 1969: The experimental approach to the taxonomy of the Myxomycetes. - Mycologia 61: 219-239.

Farr, M. 1976: Flora Neotropica 16, Myxomycetes. - 304 pp. New York.

Gray, W. \& Alexopoulos, C. 1968: Biology of the Myxomycetes. -288 pp. New York.

Hagelstein, R. 1944: The Mycetozoa of North America. 306 pp., 16 pls. Mineola, N. Y.

Härkönen, M. \& Koponen, H. 1978: Myxomycetes developed on cereal seeds in moist chamber cultures. - Karstenia 18: in preparation.

Keller, H., Aldrich, H., Brooks, T. \& Schonknecht, J.
1975: The taxonomic status of Badhamia ovispora: A Myxomycete with unique spores. - Mycologia 67: $1001-1011$.

Lister, A. 1925: A monograph of the Mycetozoa. 3rd ed., revised by G. Lister. - 296 pp., 222 pls. London.

Lister, G. 1921: New or rare species of Mycetozoa. - J. Bot. 59: 89-93.

Martin, G. \& Alexopoulos, C. 1969: The Myxomycetes. $560 \mathrm{pp}$. Iowa City.

Smart, R. 1937: Influence of certain external factors on spore germination in the Myxomycetes. - Am. J. Bot. 24: $145-159$.

Accepted for publication

on March 15, 1978 